\title{
Assessment of Phyto-Constituents by GC-MS and Anti-Tumour Activity of Garlic Grown in Different Altitude: A Comparative Study
}

\author{
Susha Antony ${ }^{1}$, Kunnambath Krishna Kumar ${ }^{1,2, *}$, Jalaja Sudhi Menon ${ }^{3}$
}

\section{Susha Antony ${ }^{1}$, Kunnam- bath Krishna Kumar ${ }^{1,2, *}$, Jalaja Sudhi Menon ${ }^{3}$}

\author{
'Department of Pharmaceutical \\ Chemistry, St James College of \\ Pharmaceutical Sciences, Chalakudy, \\ Kerala, INDIA. \\ ${ }^{2}$ St James Hospital Trust Pharmaceutical \\ Research Centre (DSIR Recognized), \\ Chalakudy, Kerala, INDIA. \\ ${ }^{3}$ Kerala Agriculture University, College \\ of horticulture, Vellanikkara, Trissur, \\ Kerala, INDIA.
}

Correspondence

Kunnambath Krishna Kumar

St James Hospital Trust Pharmaceutical Research Centre (DSIR Recognized),

Chalakudy, Kerala, INDIA.

Phone no : 0480- 2710937

E-mail: stjamespharmacyproject@gmail. com

History

- Submission Date: 16-05-2018;

- Review completed: 22-10-2018;

- Accepted Date: 22-11-2018

DOI : 10.5530/pj.2019.11.52

Article Available online

http://www.phcogj.com/v11/i2

Copyright

(C) 2019 Phcog.Net. This is an openaccess article distributed under the terms of the Creative Commons Attribution 4.0 International license.

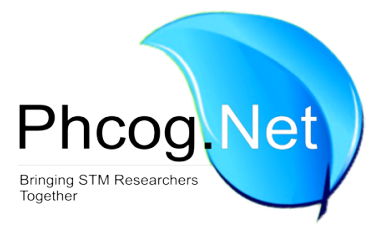

\begin{abstract}
Background: Garlic (Allium sativum L.) is most important spice containing highest sources of total phenolic compounds. It has been used as a component of traditional and modern medicine. Pharmacological properties of garlic is mainly depend on its phyto-constituents content, which varies between geographical regions. The aim of this study was to evaluate and compare the phyto-constituents content of garlic sample collected from high ranges of Idukki (Kanthallur) with that of Tamil Nadu (Mettupalayam market) garlic sample. Materials and Methods: garlic clove sample were collected from high ranges of kanthallur region (GSK) and Mettupalayam region (GSM). The garlic oil was extracted from the collected garlic sample by solvent extraction method. The phytochemical study of extracted garlic oil were conducted using standard methods of analysis and subjected GC-MS analysis. Further, the extracted oil samples were studied for their anti-tumour activity against Dalton Lymphoma Cell Lines (DLA) in an in vitro model. Results: The obtained results revealed that garlic oil of GSK showed highest percentage of yield of oil $(1.1 \%)$ than garlic oil of GSM $(0.6 \%)$. The phytochemical screening of GSK indicated the presence of alkaloids and flavonoid, whereas GSM showed presence of alkaloids only. GC-MS analysis of garlic oil study indicated that garlic oil of GSK was found to have eugenol as a novel source compared with garlic oil of GSM. Garlic oil of GSK showed significant anti-tumour activity against DLA cells, compared with garlic oil of GSM. Conclusion: Garlic oil of GSK exhibited potential anti-tumour activity against DLA cells due to presence of eugenol compound as novel source.

Key words: Garlic oil, Phyto-Constituents, GC-MS, Anti-tumour, MTT.
\end{abstract}

\section{INTRODUCTION}

The native of the Garlic (Allium sativum L.) is Central Asia and it has been used throughout history for both food and medical purposes. The garlic or garlic extracts or garlic oil are used as food supplementary agents to treat human diseases such as diabetes, cancer, hypertension and atherosclerosis. ${ }^{1}$ It is commonly believed that pharmacological properties of a fresh garlic extract/oil are mostly due to presence of sulfur compounds or non-sulfur compounds including polyphenolics. Some of the garlic studies showed the synergistic pharmacological action due to proportion of different biological constituents present in a garlic clove. $^{2}$

Garlic contains 0.1 to $0.36 \%$ essential oil, the principal components of which are diallyl disulfide, diallyl trisulfide, allyl propyl disulphide. Allicin is the main active constituent and a yellow liquid responsible for the odour of garlic. The regular intake of garlic oil can decrease blood pressure; prevent heart disease including atherosclerosis and cancer. ${ }^{3}$ Garlic extracts or oil obtained from garlic bulbs exhibited prevention of oxidative modification of DNA, lipids and proteins by scavenging Reactive Oxygen Species (ROS) and enhancing the antioxidant enzymes at cellular level. Polyphenolic compounds are showing potential antioxidant activity and some epidemiological studies expressed the correlation between an intake of polyphenols in supplementary diet and preventive effects on diabetes, cancer and neurodegenerative diseases. Contents of phyto-chemical compounds in garlic vary in different geographical regions. ${ }^{4}$ The aim of the present study was to compare the phytochemical and pharmacological properties of two garlic species, grown in different regions such as kanthallur (Idukki) region (GSK) and Mettupalayam region (GSM). The garlic oil was extracted from two different garlic sample collected from high ranges of Idukki (Kanthallur) with that of Tamil Nadu (Mettupalayam). Extracted garlic oils was subjected to qualitative phytochemical analysis and GC-MS analysis. Further, in vitro cytotoxic potential of garlic oils was evaluated against DLA cells.
Cite this article: Antony S, Kumar KK, Menon JS. Assessment of Phyto-Constituents by GC-MS and Anti-Tumour Activity of Garlic Grown in Different Altitude: A Comparative Study. Pharmacog J. $2019 ; 11(2): 350-54$. 


\section{MATERIAL AND METHODS}

\section{Reagents}

Petroleum ether $\left(60-80^{\circ} \mathrm{C}\right)$, n-hexane, ethyl acetate, ethanol, Glacial acetic acid, Sodium sulphate were purchased from Loba Chemie, Mumbai. Dalton Lymphoma cells procured from National Centre for Cell science (NCCS), Pune, India. Sterile 96-well plates were obtained from Tarson, India. Roswell Park Memorial Institute (RPMI) Medium, thiazolyl blue tetrazolium bromide (MTT), Fetal bovine serum (FBS), L-glutamine, penicillin, sodium pyruvate were procured from Hi-Media, India.

\section{Preparation of garlic oil}

Garlic bulbs (Allium sativum; family: Liliaceae) were collected from local plantations of high ranges of Idukki (Kerala species name: GSK), Kerala and Mettupalayam (Tamil Nadu species name: GSM), Tamilnadu. The collected garlic samples were authenticated by Dr. Jalaja S Menon, Department of Horticulture, Kerala Agricultural University, Thrissur, Kerala (Voucher No. SJCOPS/GS/05/2017). Garlic bulbs of GSK (100 gm) were crushed and crushed garlic species were subjected to hydro-distillation with $100 \mathrm{ml}$ of distilled water using Clevenger apparatus for $5 \mathrm{~h}$. On condensation oil-rich and water-rich layers were formed. These oil and water layers are separated by decantation. The percentage yield of garlic oil from GSK was $1.1 \%(\mathrm{w} / \mathrm{v})$. The collected garlic oil was then dried using anhydrous sodium sulphate and kept sealed in dark glass vial. The same oil extraction procedure was repeated with 100gm of garlic bulbs of GSM in order to obtain garlic oil. The percentage yield of garlic oil from GSM was $0.6 \%(\mathrm{w} / \mathrm{v})$.

\section{Preliminary qualitative phytochemical analysis}

Preliminary qualitative phytochemical analysis was carried out to identify the phytochemical constituents present in the garlic oil of GSK and GSM sample. ${ }^{5,6}$

\section{Gas chromatography-Mass spectrometry (GC-MS) Analysis \\ Preparation of garlic oil samples of GSK and GSM for GC-MS analysis}

Garlic oil was diluted with 7\% by chloroform. An inert gas (nitrogen) was introduced, from a large gas cylinder through the injection part, the column and the detector. The flow rate of the carrier gas was adjusted to confirm reproducible retention time and to reduce detector dirt. The sample was injected using a micro-syringe through a heated injection part when it was vaporized and carried into the column. The long tube of the column was tightly packed with solid particles. The mobile and stationary phases were then partitioned by the samples and it was separated into the individual components. The carrier gas and sample component was then emerging from the column and passed through a detector. The amount of each component as concentration by the device and generates a signal which was registered electrically. The signal passed to a detector.

\section{GC-MS Analysis}

The garlic oil of two varieties of Allium sativum (GSK and GSM) were analyzed by Electron Impact Ionization method on GC- 17A gas chromatography with slight modification. ${ }^{7}$ GC-MS was coupled to a GC-MS 2010 plus mass spectrometer. GC-MS was fused silica capillary column temperature of $40^{\circ} \mathrm{C}$ was maintained with carrier gas helium at a constant pressure of $90 \mathrm{kPa}$. Samples were injected by splitting with the split ratio 10. Garlic oil sample of GSK was dissolved in chloroform. The operating condition were as follows: name of column- RTS-5MS, diameter $30 \mathrm{~cm}$, length $0.25 \mathrm{~mm}$, temperature of the column initial temperature $40^{\circ} \mathrm{C}$, injector temperature $220^{\circ} \mathrm{C}$, holding time $5 \mathrm{~min}$, column packing- column packing was done with $10 \%$ diethylene glycol succinate on 100-120 mesh diatomic CAW, splitting- samples were injected by splitting with the spilt ratio 10, carrier gas- helium gas at constant pressure $90 \mathrm{kPa}$, sample dissolved- in chloroform, range of linear temperature increased $10^{\circ} \mathrm{C}$ per min. The same procedure of Gas chromatography-mass spectrometry (GC-MS) analysis was performed for GSM garlic oil.

\section{In vitro anti-tumour activity}

The in vitro anti-tumour activity of extracted GSK and GSM garlic oil against Dalton Lymphoma cells was studied using MTT assay with slight modification. ${ }^{8}$ The 3-(4,5-dimethylthiazol-2,5-diphenyltetrazolium bromide) dye reduction assay was conducted to diagnose the antitumour activity of garlic oil of GSK and GSM sample at different concentrations. Briefly $1 \mathrm{~mL}$ of $1 \times 106$ DLA cells was seeded in RPMI1640 medium supplemented with 10\% fetal bovine serum, streptomycin $(100 \mu \mathrm{g} / \mathrm{mL})$ and penicillin $(100$ units $/ \mathrm{mL})$ and incubated in a carbon dioxide incubator with $0.1 \%$ DMSO (vehicle). Cells in the exponential phase was harvested and counted using a haemocytometer with the aid of trypan blue solution. The cell suspensions were dispensed in triplicate into 96-well culture plates at optimized concentrations. After $48 \mathrm{~h}$ incubation of Dalton's lymphoma (DL) cells in various volume $(0.1 \mathrm{ml}, 0.2 \mathrm{ml}, 0.3 \mathrm{ml}, 0.4 \mathrm{ml}, 0.5 \mathrm{ml})$ of GSK garlic oil, cells were incubated with MTT (3-(4, 5- dimethylthiazol-2-yl)-2, 5-diphenyl tetrazolium bromide) reagent for $48 \mathrm{~h}$ in the incubator. Dimethyl sulfoxide (DMSO) was added to dissolve the precipitate formed inside the living cells. The coloured formazan product was assayed spectrophotometrically at $570 \mathrm{~nm}$ using ELISA plate reader which corresponds to the cell viability. The same procedure was followed for GSM garlic oil in order to determine its anti-tumour activity against Dalton's lymphoma (DL) cells.

\section{Statistical Analysis}

Experiments were performed in triplicates. Data were presented as means \pm SDs. All anti-tumour results were compared with relevant control using student's $t$-test and a $P<0.05$ was considered significant.

\section{RESULTS AND DISCUSSION}

Garlic oil was extracted from garlic cloves of GSK and GSM sample by steam distillation using Clevenger apparatus and percentage yield of garlic oil were shown in Table 1.

Qualitative phytochemical analysis was performed for GSK and GSM garlic oil using standard methods and results were exhibited in Table 2. The phytochemical study revealed that garlic oil of GSK showed positive results for presence of alkaloids and flavonoid. But, garlic oil of GSM showed positive results for alkaloids only.

\section{Gas chromatography-Mass spectrometry Analysis}

The biological active constituents of garlic oil of GSK and GSM were compared through GC-MS analysis (Table 3 and 4). The results indicated that GSK garlic oil containing principal components such as 3- Vinyl1, 2-dithiacyclohex-4-ene (1.09\%), trisulfide (0.285), diallyl disulphide (7.21\%), hexadecanoic acid (1.02\%) and eugenol (5.645). But the GSM garlic oil containing 3-Vinyl-1, 2-dithiacyclohex-4-ene (1.40\%), trisulfide (1.49\%), diallyl disulphide (0.33\%), hexadecanoic acid (5.38\%). The GC-MS study results indicated novel biological compound such as eugenol (Figure 1) was detected only in garlic oil of GSK, whereas absent in garlic oil of GSM.

Our results showed that garlic oil from both of the two varieties from two different places (GSK and GSM) containing complex mixture of numerous phytochemical compounds, many phyto-constitutents are found in trace amount. From our study, it was found that eugenol as novel compound in GSK variety of garlic sample. This confirms that the reported 
Table 1: Percentage yield of garlic oil.

\begin{tabular}{ccc}
\hline S. No & Sample & Percentage yield (\%v/wt) \\
\hline 1 & GSK (Garlic Species from Kanthallur) & $1.1 \%$ \\
2 & GSM (Garlic Species from & $0.6 \%$ \\
& Mettupalayam) & \\
\hline
\end{tabular}

Table 2: Phytochemical analysis of garlic oil.

\begin{tabular}{cccc}
\hline $\begin{array}{c}\text { Phytochemical } \\
\text { constituents }\end{array}$ & Phytochemical test & GSK & GSM \\
\hline Carbohydrates & Molish's test & - & - \\
& Benedict's test & - & - \\
Alkaloids & Dragendroff's test & + & + \\
& Mayer's test & + & + \\
& Wagner's test & + & + \\
& Hager's test & + & + \\
Flavonoids & Lead acetate test & + & - \\
Terpenoids & Libermann-buchard & - & - \\
Glycosides & Keller killiani test & - & - \\
& Borntrager's Test & - & - \\
\hline
\end{tabular}

[+]: Present; [-]: Absent

Table 3: Gas chromatography-Mass spectrometry (GC-MS) Analysis of GSK garlic oil.

\begin{tabular}{cccc}
\hline Sample & $\begin{array}{c}\text { Retention } \\
\text { Time (RT) } \\
\text { in min }\end{array}$ & Name of the compound & $\begin{array}{c}\text { Peak area } \\
\text { (\%) }\end{array}$ \\
\hline GSK garlic oil & 4.32 & $\begin{array}{c}\text { 3- Vinyl-1,2- } \\
\text { dithiacyclohex-4-ene }\end{array}$ & 1.095 \\
& 5.26 & Trisulfide & 0.28 \\
& 16.01 & Diallyl disulphide & 7.21 \\
21.46 & Hexadecanoic acid & 1.02 \\
5.70 & Eugenol & 5.64 \\
\hline
\end{tabular}

Table 4: Gas chromatography-Mass spectrometry (GC-MS) Analysis of GSM garlic oil.

\begin{tabular}{cccc}
\hline Sample & $\begin{array}{c}\text { Retention } \\
\text { Time (RT) } \\
\text { in min }\end{array}$ & Name of the compound & Peak area (\%) \\
\hline GSM garlic oil & 23.16 & $\begin{array}{c}\text { 3- Vinyl-1,2- } \\
\text { dithiacyclohex-4-ene }\end{array}$ & 1.40 \\
& 17.78 & Trisulfide & 1.49 \\
18.61 & Diallyl disulphide & 0.33 \\
47.19 & Hexadecanoic acid & 5.38 \\
\hline
\end{tabular}

phyto-constitutents variation in the garlic oil is due to geographic and ecological conditions.

\section{Inhibition of Dalton Lymphomas (DL) cells proliferation by garlic oil}

MTT assay was used to examine the anti-tumour activity of GSK and GSM garlic oil on Dalton Lymphomas cells for $48 \mathrm{hr}$. Data expressed from MTT experiments indicated that GSK and GSM garlic oil reduces

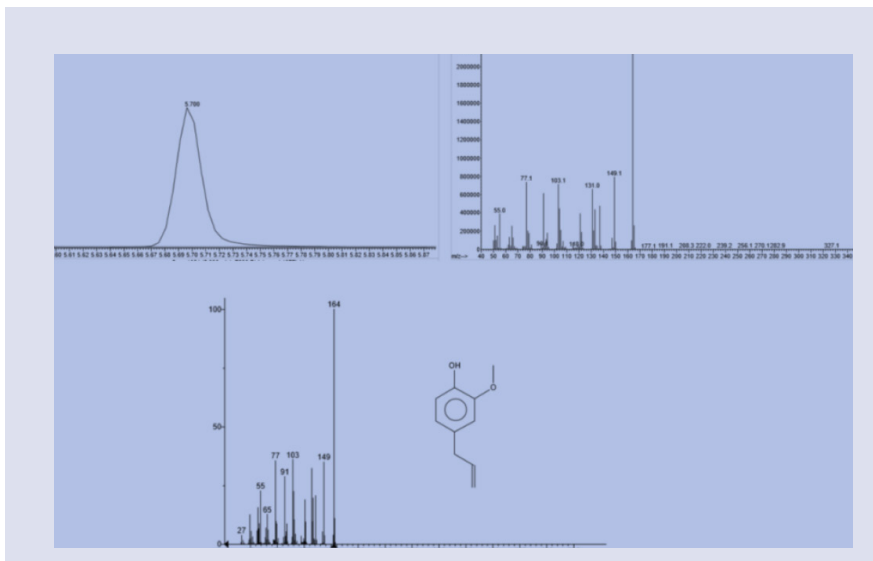

Figure 1: GC-MS Analysis of Garlic oil of GSK containing Eugenol.

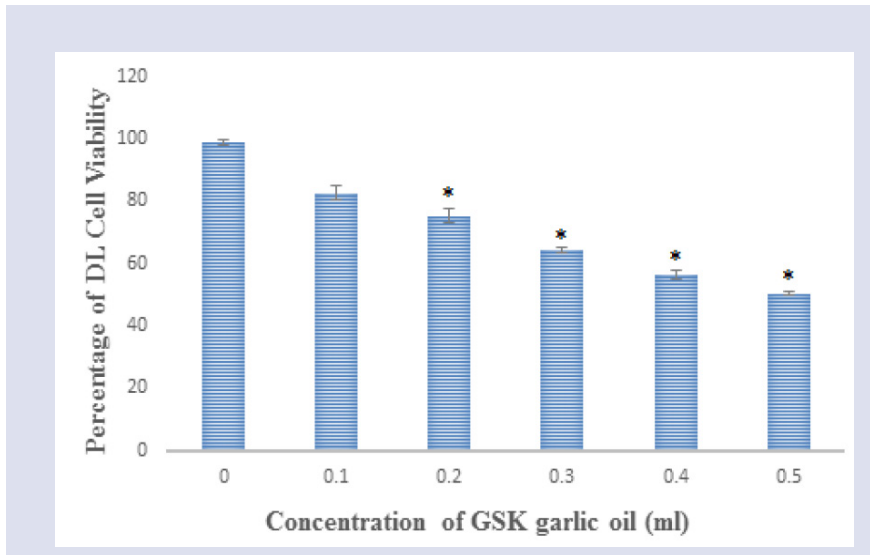

Figure 2: Anti-tumour activity of GSK garlic oil to Dalton lymphoma (DL) cells. DL cells were treated with amount of garlic oil in particular volume $(0.1 \mathrm{ml}, 0.2 \mathrm{ml}, 0.3 \mathrm{ml}, 0.4 \mathrm{ml}$ and $0.5 \mathrm{ml})$ for $48 \mathrm{~h}$. Each point represents a mean \pm SD of 3 experiments with 6 replicates per dose. *Significantly different $(p<0.05)$ from the control, according to the student's $t$-test.

the viability of Dalton Lymphomas cells in a volume-dependent fashion. GSK garlic oil significantly reduces the viability of Dalton Lymphomas cells in a volume-dependent fashion. Higher percentages of non-viable DL cells were observed in cells treated at high volume of GKS garlic oil within the range doses of $0.4 \mathrm{ml}$ (\% cell viability $56.33 \pm 1.20 \%$ ) and $0.5 \mathrm{ml}$ (\% cell viability $50.30 \pm \mathbf{0 . 4 7 \%}$ ) (Figure 2 ). But, lowest percentages of non-viable DL cells were observed in cells treated at high volume of GKM garlic oil within the range doses of $0.4 \mathrm{ml}$ (\% cell viability $71 \pm 1.24 \%$ ) and $0.5 \mathrm{ml}$ (\% cell viability $69 \pm 0.81 \%$ ) (Figure 3 ).

Several garlic extract and its bioactive compounds have been reported for anti-tumour activity with various cancer/tumour cell lines. Szychowski et al. 2016 reported the determine the involvement of Reactive Oxygen species (ROS) production in the viability and apoptosis in human tongue squamous carcinoma (SCC-15) cell line after exposure to two Allium sativum L. cultivars, Harnaś and Morado. This study suggested that garlic Polish cultivar Harnaś manifested more prolonged potential to stimulate ROS production in human squamous carcinoma (SCC-15) cells. ${ }^{9}$ Yedjou et al. 2012 evaluated whether or not garlic extract-induced cytotoxicty and apoptosis in Human Leukemia (HL-60) cells is mediated 


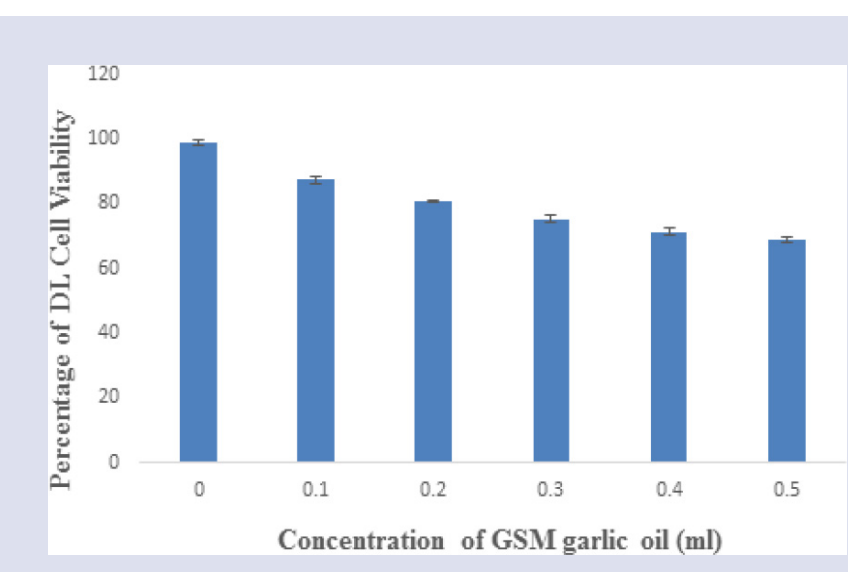

Figure 3: Anti-tumour activity of GSM garlic oil to Dalton lymphoma (DL) cells. DL cells were treated with amount of garlic oil in particular volume $(0.1 \mathrm{ml}, 0.2 \mathrm{ml}, 0.3 \mathrm{ml}, 0.4 \mathrm{ml}$ and $0.5 \mathrm{ml})$ for $48 \mathrm{~h}$. Each point represents a mean \pm SD of 3 experiments with 6 replicates per dose. *Significantly different $(p<0.05)$ from the control, according to the student's $t$-test.

through oxidativestressand this studyindicated thatgarlicextract-induced cytotoxicity and apoptosis in HL-60 cells involve phosphatidylserine externalization, caspase- 3 activation and nucleosomal DNA fragmentation associated with the formation of MDA, a by-product of lipid peroxidation and biomarker of oxidative stress. ${ }^{10}$ Sundaram et al. $1996 \mathrm{com}$ pared the effects of various oil-soluble compounds containing allyl and disulfide groups on the proliferation of cultured Human Colon Tumor cells (HCT-15) and study found that Diallyl Disulfide (DADS) was more effective in inhibiting the growth of HCT-15 cells than isomolar concentrations of S-allyl cysteine, Dipropyl Disulfide (DPDS), allyl chloride, allyl glycidyl ether and allyl alcohol. ${ }^{11}$ Jaganathan et al. reported the antiproliferative activity and molecular mechanism of the eugenol induced apoptosis against the cancer cells and animal models. ${ }^{12}$ Fadilah et al. 2017 studied the anticancer activity of combination simple aromatic benzoate compounds and eugenol against colon cancer cell line HCT 116. The study results indicated that simple aromatic benzoate compounds and eugenol as phenolic compounds showed potential effects on inhibiting colorectal cancer cells. ${ }^{13}$

Although various anti-tumour/anti-cancer agents exist, still we could not find a single drug effective in all ways. Since in each individual the effect of cancer/tumour is not same, search for new drugs seems inconclusive. Already garlic extracts have been shown to have anti-cancer/ anti-tumour activity. But no research provided confirmation for the active compound responsible for it. In the present study, we had provided have anti-cancer/anti-tumour evidence for the novel isolated active compounds namely: eugenol from garlic oil of GSK.

\section{CONCLUSION}

In the present study, our results indicated that garlic oil from two different places of Kanthalloor (Kerala) and Mettupalayam (Tamilnadu) having mixture of many compounds, which are present in trace amount and found new source of eugenol in the GSK sample. We examined antitumour activity of garlic oil and results showed that garlic oil of GSK showed significant anti-tumour activity against DLA cells due to presence of new source of eugenol compared with garlic oil of GSM. This study confirms that the reported phytochemical variation in the garlic oil is due to geographic divergence and ecological conditions. However, further in vivo investigations are needed to understand the mechanisms of anti-proliferative effects and apoptosis induced by eugenol present in GSK.

\section{ACKNOWLEDGEMENT}

The author(s) are expressing sincere thanks to management, St James College of Pharmaceutical Sciences, Chalakudy and Kerala Agriculture University, College of horticulture, Vellanikkara, Trissur, providing support for research facilities. We also acknowledge and cordially thank to Kerala State Council for Science, Technology and Environment, Thiruvananthapuram for financial support for PG projects under student project scheme.

\section{CONFLICT OF INTEREST}

The authors declare no conflict of interest.

\section{ABBREVIATIONS}

GSK: Garlic Species from Kanthallur; GSM: Garlic Species from Mettupalayam; MTT: 3-(4,5-dimethylthiazol-2-yl)-2,5-diphenyltetrazolium bromide; DL: Dalton Lymphoma; DADS: Diallyl disulphide.

\section{REFERENCES}

1. Nair SS, Gaikwad SS, Kulkarni SP, Mukne AP. Allium sativum constituents exhibit anti-tubercular activity in vitro and in raw 264.7 mouse macrophage cells infected with mycobacterium tuberculosis H37Rv. Pharmacogn Mag. 2017;13(2):S209.

2. Antony S, Krishnakumar K. Garlic and its constituents: pharmacological action: a review. Asian J Res Chem Pharm Sci. 2017;5(1):27-32.

3. Nicastro HL, Ross SA, Milner JA. Garlic and onions: their cancer prevention properties. Cancer Prev Res (Phila). 2015;8(3):181-9.

4. Bayan L, Koulivand PH, Gorji A. Garlic: a review of potential therapeutic effects. Avicenna J Phytomed. 2014;4(1):1-14.

5. Harborne JB. Phytochemical methods - a guide to modern techniques of plant analysis. $2^{\text {nd }}$ ed. London: Chapman and Hall. 1984;4-16.

6. Trease G, Evans SM. Pharmacognosy. 15 th ed. London: Bailer Tindal. 2002;23-67.

7. Lee SN, Kim NS, Lee DS. Comparative study of extraction techniques for determination of garlic flavour components by gas chromatography- mass spectrometry. Anal Bioanal Chem. 2003;377(4):749-56.

8. Adhvaryu MR, Reddy N, Parabia MH. Antitumor activity of four ayurvedic herbs in Dalton Lymphoma ascites bearing mice and their short-term in vitro cytotoxicity on DLA- cell-line. Afr J Tradit Complement Altern Med. 2008;5(4):1-6.

9. Szychowski KA, Binduga UE, Rybczynska-Tkaczyk K, Leja ML, Gminski J. Cytotoxic effects of two extracts from garlic (Allium sativum L.) cultivars on the human squamous carcinoma cell line SCC-15. Saudi J Biol Sci. 2016;1:1-9.

10. Yedjou CG, Tchounwou PB. In vitro assessment of oxidative stress and apoptotic mechanisms of garlic extract in the treatment of acute promyelocytic leukemia. J Cancer Sci Ther. 2012;2012(Suppl 3):006.

11. Sundaram SG, Milner JA. Diallyl disulfide induces apoptosis of human colon tumor cells. Carcinogenesis. 1996;17(4):669-73.

12. Jaganathan SK, Eko S. Anti-proliferative and molecular mechanism of eugenolinduced apoptosis in cancer cells. Molecules. 2012;17(6):6290-304.

13. Fadilah F, Andrajati R, Yanuar A, Arsianti A. In-vitro anticancer activity combination of eugenol and simple aromatic benzoate compounds against human colon HCT-116 cells. Int J Pharm Sci Res. 2017;9(5):637-41. 
GRAPHICAL ABSTRACT

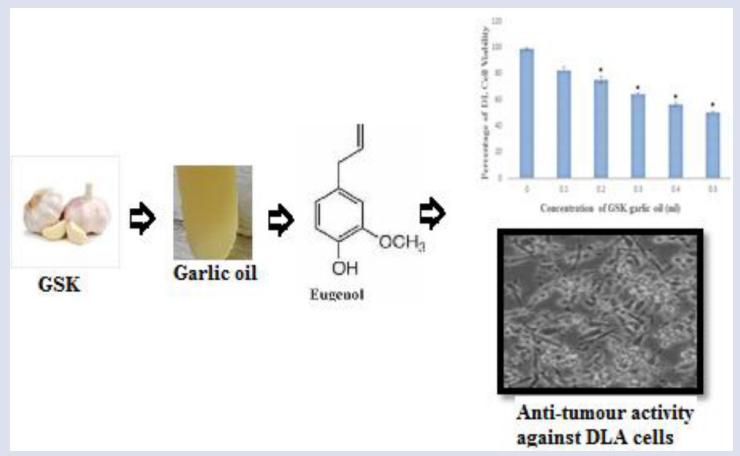

Dr. Jalaja Sudhi Menon, M.Sc., Ph.D., HOD In-Charge, Cashew Research Station, Madakkathara, Kerala Agriculture University (KAU), Thrissur, Kerala. Her research area includes Herbs, medicinal plants and spices.

\section{SUMMARY}

- GSK garlic oil showed anti-tumour activity against Dalton Lymphoma cells in an in vitro model due to presence of new source of eugenol compared with garlic oil of GSM. This study indicated that eugenol content in the garlic oil of GSK due to geographic divergence and ecological conditions.

\section{ABOUT AUTHORS}

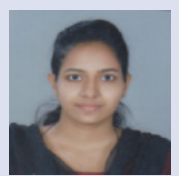

Ms. Susha Antony, Completed M.Pharm (Pharmaceutical Chemistry), at St James College of Pharmaceutical Sciences, Chalakudy, Kerala. Her research area includes phytochemistry and pharmacology.

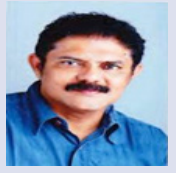

Kunnambath Krishna Kumar, M.Pharm., Ph.D., Principal, St James College of Pharmaceutical Sciences, Chalakudy. His research area includes synthesis of semi-synthetic drugs and Tissue Engineering.

Cite this article: Antony S, Kumar KK, Menon JS. Assessment of Phyto-Constituents by GC-MS and Anti-Tumour Activity of Garlic Grown in Different Altitude: A Comparative Study. Pharmacog J. 2019;11(2):350-54. 